\title{
Initial stages of indoor atmospheric corrosion of electronics contact metals in humid tropical climate: tin and nickel*
}

\author{
L. Veleva***, L. Dzib-Pérez***, J. González-Sánchez**** and T. Pérez***
}

\begin{abstract}
Samples of electrolytic tin and nickel have been exposed for 1 to $12 \mathrm{~m}$ in indoor environment, inside a box (rain sheltered cabinet), placed in tropical humid marine-urban climate, as a part of Gulf of Mexico. The corrosion aggressiveness of box has been classified as a very high corrosive, based on the monitored chlorides and $\mathrm{SO}_{2}$ deposition rates, and the Temperature/Relative Humidity air daily complex. The annual mass increasing of nickel is approximately twice higher than its values of mass loss (C). The relation between nickel mass loss or increasing and time of wetness $(t)$ of metal surface is linear and does not obey the power equation $C=A t^{n}$, which has be found for tin. The SEM images reveal a localized corrosion on nickel and tin surfaces. XRD detects the formation of $\mathrm{SnCl}_{2} \cdot \mathrm{H}_{2} \mathrm{O}$ as a corrosion product. Within the time on the tin surface appear black spots, considered as organic material.
\end{abstract}

\section{Etapas iniciales de corrosión atmosférica indoor de metales electrónicos de contacto en clima tropical húmedo: estaño y níquel}

\begin{abstract}
Resumen
Muestras de estaño y níquel electrolíticos han sido expuestas de 1 a $12 \mathrm{~m}$ en ambiente interno (indoor), en una caseta (gabinete protegido de lluvia), colocada en clima tropical húmedo marino-urbano del Golfo de México. La agresividad de la caseta ha sido clasificada como muy altamente corrosiva, basada al registro de la velocidad de deposición de cloruros y $\mathrm{SO}_{2}$, y en el complejo diario de temperatura/humedad relativa del aire. El incremento de masa anual de níquel es, aproximadamente, dos veces mayor que del valor de su pérdida de masa $(C)$. La relación entre la pérdida de masa de Ni o su incremento, y el tiempo de humectación $(t)$ de la superficie metálica y lineal y no obedece la ley de potencia $C=A t^{n}$, que ha sido encontrada para el estaño. Las imágenes del SEM revelan una corrosión localizada en las superficie de níquel y estaño. El análisis de rayos-X detecta la formación de $\mathrm{SnCl}_{2} \cdot \mathrm{H}_{2} \mathrm{O}$ como producto de corrosión. Con el tiempo, sobre la superficie de estaño aparecen puntos negros, considerados como materia orgánica.
\end{abstract}

Palabras clave

Corrosión atmosférica Indoor. Estaño. Níquel. Clima tropical marino.

\footnotetext{
* Trabajo recibido el día 11 de julio de 2006 y aceptado en su forma final el día 3 de noviembre de 2006.

** Center for Investigation and Advanced Study (CINVESTAV), Applied Physics Department, Carr. Ant. a Progreso Km.6, C.P. 97310, Merida, Yuc., Mexico, veleva@mda.cinvestav.mx.

*** Universidad Autónoma de Campeche, Programa de Corrosión de Golfo de México, Agust. Melgar S/N, C.P. 24030, Campeche, Camp., México, jagonza/@uacam.mx.
} 


\section{INTRODUCTION}

Corrosion in the electronics industry has become a significant factor in recent years because of the extremely complex system that have been developed and the increasing demand on their reliability ${ }^{[1-6]}$. It is noted that further advances in electronics can only be made where its reliability and corrosion failure are maintained. However, testing for corrosion behavior is still difficult and costly. Electronic materials include a range of metals and alloys, depending on the specific system, equipment and components. Many metals are used and tin (or tin alloys), and nickel $(\mathrm{Au} / \mathrm{Ni} / \mathrm{Cu})$ are part of any electronic system. It is reported that the failure processes in the electronic industry, because of corrosion, prevail when circuits boards are exposed to relatively high humidity (>60\%) and ionic contamination, as it is common in many urban, suburban, coastal and industrial environments. By nature of thin film and closely-spaced metallic sections in small dimensions in electronic circuits, electronic components are prone to corrosion failures of a device for a short period (less than one year), generated by localized corrosion currents $\left(10^{-12}-10^{-14} \mathrm{~A}\right)$ in the presence of trace of moisture and contamination. With submicron dimensions of conductors, only nanograms of metal need to corrode and to cause total failure of an electronic device ${ }^{[3-5]}$

Tin (Sn) is widely used in the electronic industry for carious purposes such as in tin-lead alloys as soldering materials and in coating on structural materials as connectors ${ }^{[7-10]}$. For these proposes they are required to be with a high corrosion resistance and protection, providing a low degree of contact impedance. The solder corrosion on $\mathrm{Sn}-\mathrm{Pb}$ alloys is one of the reliability problem confronted in electronic equipments. Pure tin forms a protective oxide (most likely SnO) film, but lead forms an oxide that is not stable and can easily react with chlorides, borates, and sulfates. Led-free solders have been developed recently to prevent pollution of the environment with lead, and they are now being used in practice.

To obtain a fundamental understanding on the corrosion behavior of tin in corrosive gas environment, in situ infrared reflection (IR) absorption spectroscopy measurements have been carried out on tin in humid air ( $\mathrm{RH}$ of $90 \%$ ) containing $\mathrm{SO}_{2}(10-22 \mathrm{ppm})^{[7]}$. The results suggest that the oxide films on tin $\mathrm{SnO}_{2}$ and/or $\mathrm{SnO}$ ) have a protective effect and that no significant corrosion occurred. In humid air (RH of 80-90 \%) containing 10-22 ppm $\mathrm{NO}_{2}$, the chemical species produced on the tin surface are assigned to $\mathrm{SnO}$ and/or $\mathrm{SnO}_{2}$, nitrate and hyponitrite. Synergistic effect of $\mathrm{SO}_{2}$ and $\mathrm{NO}_{2}$ on corrosion of tin has not been observed in humid air ( $\mathrm{RH}$ of $90 \%$ ), containing $0.84 \mathrm{ppm} \mathrm{SO}_{2}$ and $1.8 \mathrm{ppm} \mathrm{NO}_{2}$. In acidic water layer, the tin oxides dissolve ${ }^{[8]}$ as follows and bare surface of tin appears:

$$
\begin{aligned}
& \mathrm{SnO}_{2}+4 \mathrm{H}^{+} \rightarrow \mathrm{Sn}^{+4}+\mathrm{H}_{2} \mathrm{O} \\
& \mathrm{SnO}+2 \mathrm{H}^{+} \rightarrow \mathrm{Sn}^{+2}+\mathrm{H}_{2} \mathrm{O}
\end{aligned}
$$

Tin oxides $\mathrm{SnO}$ and $\mathrm{SnO}_{2}$ give very similar binding energies of $\mathrm{Sn}_{3 \mathrm{~d} 5 / 2}$ (486.6; 486.4, respectively and 484.5 for tin) and for this reason it is not possible to distinguish them, even using additionally XPS analysis. IR spectra suggest that $\mathrm{SnO}_{2}$ is the main corrosion product.

Nickel (Ni) has found application in the electronics industries as a coating in multilayer systems $(\mathrm{Cu} / \mathrm{Ni} / \mathrm{Cr}$ or $\mathrm{Cu} / \mathrm{Ni})$. It is a relatively resistant to corrosion, because of the oxide passive layer formed in atmospheric conditions. With increasing interest in corrosion effects of electronics, a few studies on the atmospheric corrosion of nickel have been performed, exposing the metal in indoor environment and analyzing the corrosion products with different techniques: XPS, X-ray diffraction, DRIFT (diffuse reflectance infrared diffraction), Auger spectroscopy and elemental analysis $^{[6}$ y 10-17]. It is known that the corrosion of nickel is mostly related to the $\mathrm{SO}_{2}$ concentration in the outdoor ambient air or its deposition velocity. When nickel is exposed to moist air, containing sulphur dioxide, it is covered with a wet layer of nickel sulphate, because this metal catalyses the oxidation of $\mathrm{SO}_{2}$ to sulphur trioxide $\left(\mathrm{SO}_{3}\right)$. The atmospheric corrosion of nickel in sheltered conditions has been studied in different sites in Europe and North America (USA and Canada), reported by the UN/ECE international program on effects on materials ${ }^{[10}$ y 17] . Physical and chemical information on nickel corrosion layer formation, evolution, morphology, composition is presented $\mathrm{in}^{[15]}$. The corrosion rate of nickel is a function of the exposure time and of the average concentration of sulfur dioxide:

$$
\mathrm{R}=2.4 \mathrm{t}\left[\mathrm{SO}_{2}\right]
$$

where, $R$ is the corrosion rate of nickel in sheltered conditions, expressed as mass loss $\left(\mu \mathrm{g} / \mathrm{cm}^{2}\right), t$ is the time in years, and $\left[\mathrm{SO}_{2}\right]$ is the average outdoor concentration $\left(\mu \mathrm{g} / \mathrm{m}^{3}\right)$. Thus, in relatively unpolluted environment the rate of nickel corrosion can be quite low. It is the presence of the sulfur $\left(\mathrm{S}^{\mathrm{IV}}\right)$, and not of oxidizer, that appears to be the limiting constraint. The corrosion of nickel may be manifested either uniformly or as pitting, but this metal is generally corrosion-resistant in mild environments ${ }^{[15]}$.

Electronics are exposed to a wide range of outdoor or indoor atmospheric exposure and their corro- 
INITIAL STAGES OF INDOOR ATMOSPHERIC CORROSION OF ELECTRONICS CONTACT METALS IN HUMID TROPICAL CLIMATE: TIN AND NICKEL ETAPAS INICIALES DE CORROSIÓN ATMOSFÉRICA INDOOR DE METALES ELECTRÓNICOS DE CONTACTO EN CLIMA TROPICAL HÚMEDO: ESTAÑO Y NÍQUEL

sion behavior is determined by the aggressivity of the actual environment. Electronics components are mostly indoor or sheltered from direct exposure to liquid splash, spray, rain, tinow, etc. The atmospheric corrosion, as an electrochemical process under the influence of thin-film electrolytes, is primarily responsible for corrosion damage in electronics and can lead to premature failures even in indoor atmospheres. Due to this fact, there is a growing interest in indoor environments and their specifics characterization, mainly because of the corrosion effects on electronic materials and detected failures during the last two decades. The corrosivity of indoor air can be monitored in its most simple form by placing small coupons of lead, silver, copper, etc. in the environment in questions. And for this reason have been organized around the world Indoor Air Pollutant Working Groups, to develop a general understanding of indoor air aggressivity.

In order to classify the aggressivity of different indoor environments have been proposed several systems ${ }^{[18-20]}$. An extensive field indoor exposure program on electric contact materials (nickel, tin, copper, silver and Eurocard connectors), placed in aluminum ventilated boxes, has been started in the UN ECE in 1987 (39 exposure sites) in 12 European countries and in the USA, and Canada. The evaluation of the corrosion attack on these metals after 8 years of exposure, based on weight increase measurements and mass loss determination, has been reported $^{[10,17 \text { y 20]. }}$.

In attempting to minimize the risk of corrosion failures it is important to understand the corrosion process of the metals used in electronics, exposed to indoor environments, as a part of different climates with distinct corrosive aggressiveness. Tropical humid environments present characteristics, which have effects on the performance of electro-electronic products and they are not yet satisfactorily characterized. In 2002 was started the project TROPICORR (Effects of Tropical Environments on Electro-Electronic Products) as Subprogram XV.2 of the Program of Science and Technology for Development. In different countries, with the participation of research groups was started the atmospheric exposure of several metals (tin, nickel, silver, copper), used in the electro-electronic industries, in indoor environments.

The aim of the present work was to study as accurately as possible the initial stages of atmospheric indoor corrosion of pure tin and nickel samples after their exposure for 1 to $12 \mathrm{~m}$ in rain sheltered position inside box (cabinet), placed in tropical humid urbanmarine climate, part of Southeast of Mexico (Gulf of Mexico).

\section{EXPERIMENTAL}

\subsection{Test site location}

The test was carried out in urban-marine atmosphere of Campeche city (19 $\left.51^{\prime} \mathrm{N}, 90^{\circ} 32^{\prime} \mathrm{W}\right)$, at $300 \mathrm{~m}$ away from the coast, located in southeast of Mexico, in the Caribbean area (Gulf of Mexico). Its tropical humid climate exhibits very marked dry and rainy seasons. The combination of high temperatures ( $\mathrm{T}$ ) and high annual time of wetness (TOW), due to the high constant daily and monthly relative humidity ( $\mathrm{RH}$ ) values, makes possible an accelerated electrochemical corrosion process in the presence of hygroscopic surface pollutants, such as chloride in the coastal region. In our previously study we have reported an analysis of the principal characteristics of that climate ${ }^{[21]}$.

\subsection{Samples in test}

Electrolytic $(99,99 \%)$ rectangular samples of tin $(3.5 \times 1$ $\times 0.1 \mathrm{~cm})$, nickel $(3.5 \times 1 \times 0.1 \mathrm{~cm})$ and low carbon steel $(3.5 \times 1 \times 0.1 \mathrm{~cm})$ were prepared for exposure. Samples of low carbon steel were exposed in order to estimate the category of aggressiveness of the indoor environment, using the categories proposed by ISO $1184-1^{[22]}$. The specimens before weighing (on a microbalance with the accuracy of $\pm 0.1 \mu \mathrm{g}$ ) were prepared following the procedures of ISO $11844-2^{[22]}$ and stored in plastic bags inside, placed in a desiccator.

\subsection{Exposure and environmental characterization}

The metallic samples were exposed to the indoor environment inside the box (cabinet) for different periods of time (1, 3, 6, 9 and $12 \mathrm{~m}$ ), in vertical position. The box (a rectangular cabinet of $66 \times 32 \times 71 \mathrm{~cm}$ ) was constructed using galvanized sheet, painted with a white corrosion resistive paint. Two windows of $22 \times 26 \mathrm{~cm}$ were positioned at the longitudinal ends of the cabinet, at $20 \mathrm{~cm}$ from the bottom, in order to leave the entrance end exit of the wind and contaminants. The windows were protected by stainless steel mesh. The box was positioned following the northwest direction, at the top of a building $10 \mathrm{~m}$ high, where the wind passed through freely.

The temperature $(\mathrm{T})$ and relative humidity $(\mathrm{RH})$ values were registered during the whole exposure period, comparing the outdoor and indoor T/RH complexes of both environments. The analysis of these $\mathrm{T} / \mathrm{RH}$ complexes has been used for time of wetness (TOW) estimation, as a real time for the corrosion process, according to ISO $9223^{[23]}$. Because of salinity of 


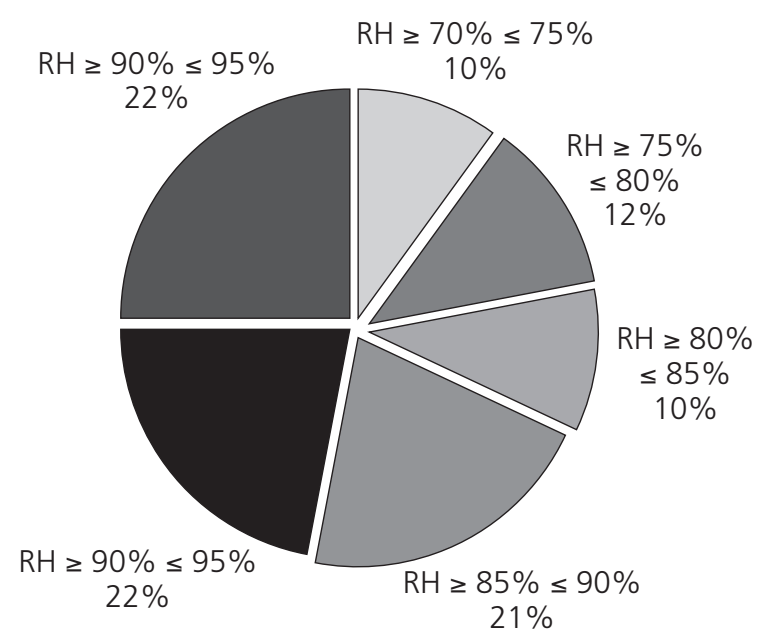

Figure 1. Annual indoor (cabinet) TOW distribution (\%) in different relative humidity intervals during the test of metal samples exposed to tropical urban-marine humid climate (Gulf of Mexico).

Figura 1. Distribución (\%) del TOW anual en el ambiente indoor (gabinete) en diferentes intervalos de humedad relativa, durante el ensayo de muestras de metales expuestas al clima tropical húmedo urbano-marino (Golfo de México).

the marine atmosphere, the TOW was calculated as the time when the $\mathrm{RH} \leq 70 \%$ (at $\mathrm{T} \leq 25^{\circ} \mathrm{C}$ ). The calculated annual TOW for the samples exposed in the indoor (cabinet) was $5622 \mathrm{~h}$ (the highest $\tau_{5}$ category of corrosion aggressiveness, according to ISO $9223^{[23]}$, which is $64 \%$ of the annual time of exposure. For outdoor environment the TOW was lower, $3250 \mathrm{~h}\left(\tau_{4}\right.$ category) or $37 \%$ of the annual time. The annual indoor TOW (5622 h) distribution in different relative humidity $(\mathrm{RH})$ intervals is shown in figure 1 . As can be seen, $31 \%$ of the TOW occurs in RH interval of $90-95 \%$, followed by RH interval of 95-100\% when the due point is reached and the condensation film is thicker. Only $15 \%$ of the TOW occurs in lower intervals of $70-$ $80 \% \mathrm{RH}$ values.

The outdoor TOW distribution is a very different from the indoor TOW distribution, and their comparison (Fig. 1) reveals some specifics of the indoor environment, created in the tested cabinet. For example, $78 \%$ of TOW in outdoor marine environment is done in the lowest RH interval of $70-85 \%$, while in indoor (cabinet) this percentage is very low (22\%). Besides, in outdoor there is not TOW registered in the RH interval of $90-100 \%$. This fact and the longer TOW for indoor (cabinet) samples determine a high corrosion rates for the metal samples exposed in the cabinet. Statistical analysis of the temperature-humidity complex and time of wetness of a tropical climate in Mexico has been reported before ${ }^{[21]}$.

Analyzing the T/RH - TOW complex, the result show that the biggest part (90\%) of annual indoor (ca-

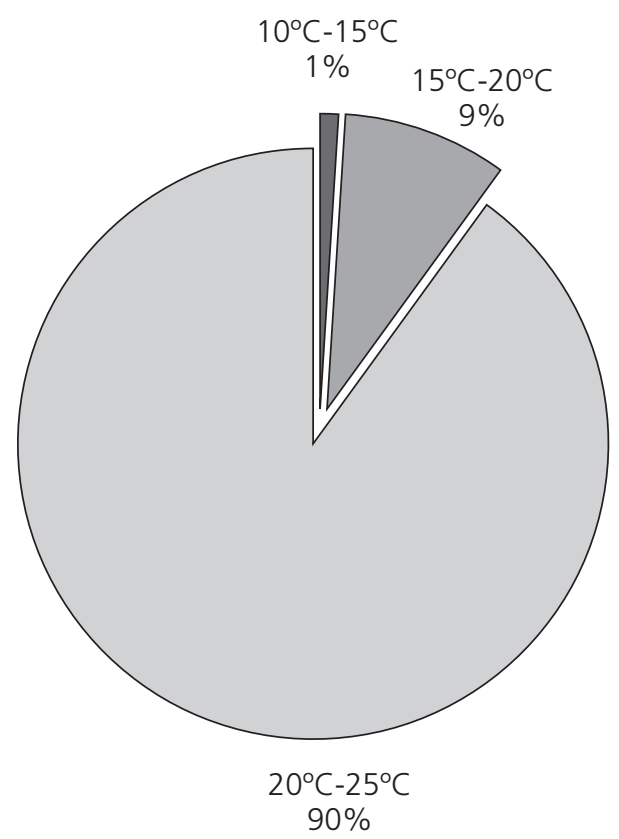

Figure 2. Annual indoor (cabinet) time of wetness (TOW) distribution in temperature ranges during the test of metal samples exposed to tropical urban-marine humid climate (Gulf of Mexico).

Figura 2. Distribución (\%) del TOW anual en el ambiente indoor (gabinete) en diferentes intervalos de temperatura, durante el ensayo de muestras de metales expuestas al clima tropical húmedo urbano-marino (Golfo de México).

binet) TOW occurs in the temperature range of $20{ }^{\circ} \mathrm{C}$ - $25^{\circ} \mathrm{C}$ (Fig. 2). Sometimes, during the rainy season (April - June, September - October) the TOW is done in the lower range of $20^{\circ} \mathrm{C}-25^{\circ} \mathrm{C}$. The annual TOW of the outdoor environment mainly (90\%) occurs in a temperature range of $20{ }^{\circ} \mathrm{C}-25^{\circ} \mathrm{C}$ and $10 \%$ in $15^{\circ} \mathrm{C}$ - $20^{\circ} \mathrm{C}$. This fact indicates that the corrosion process for the studied metals is determined by similar temperature ranges in both environments (indoor and outdoor). However, the TOW (the real corrosion time) is higher for samples exposed in indoor (cabinet) conditions and it presents some specifics, described above (Fig. 1), when is compared to outdoor TOW. Table I presents the recorded maximum and minimum temperatures in both environments (outdoor and indoor) during the annual period of this experiment.

In both environments was monitored continuously the concentration (deposition rate) of $\mathrm{SO}_{2}$ and airborn salinity (chlorides), as main contaminants ( $\mathrm{Ta}$ ble II), measured with sulfation plate and wet candle samples, respectively, according to ISO 9225[24]. As can be seen, the indoor (cabinet) environment maintains lower concentration (deposition rate) of salinity $\left(\mathrm{Cl}^{-}\right.$ions) and $\mathrm{SO}_{2}$ content, compared to the exterior environment ones, however the corresponding pollution categories for both atmospheres (outdoor and in- 
INITIAL STAGES OF INDOOR ATMOSPHERIC CORROSION OF ELECTRONICS CONTACT METALS IN HUMID TROPICAL CLIMATE: TIN AND NICKEL ETAPAS INICIALES DE CORROSIÓN ATMOSFÉRICA INDOOR DE METALES ELECTRÓNICOS DE CONTACTO EN CLIMA TROPICAL HÚMEDO: ESTAÑO Y NÍQUEL

Table I. Maximum and minimum values of temperature during the annual period of experiment

Tabla I. Valores máximos y mínimos de la temperatura durante el período anual del ensayo

\begin{tabular}{|c|c|c|c|c|c|c|}
\hline \multicolumn{7}{|c|}{ TEMPERATURE $\left({ }^{\circ} \mathrm{C}\right)$} \\
\hline \multirow[b]{2}{*}{ Period } & \multicolumn{3}{|c|}{ Indoor (cabinet) } & \multicolumn{3}{|c|}{ Outdoor } \\
\hline & Min & Max & Most frequent & Min & Max & Most frequent \\
\hline Apr - May'03 & 15.6 & 42.0 & 25 & 20.3 & 40 & 26 \\
\hline May - Jun'03 & 22.1 & 41.5 & 25 & 22.9 & 37.7 & 30 \\
\hline Jun - Jul'03 & 22.5 & 41.5 & 25 & 21.9 & 37.8 & 24 \\
\hline Jul - Aug'03 & 22.5 & 41.0 & 24 & 22.3 & 35.5 & 24 \\
\hline Aug - Sep'03 & 22.5 & 40.1 & 25 & 22.3 & 34.9 & 24 \\
\hline Sep - Oct'03 & 22.9 & 40.1 & 24 & 22.9 & 34.9 & 24 \\
\hline Oct - Nov'03 & 20.6 & 36.6 & 24 & 20.8 & 32.8 & 24 \\
\hline Nov - Dec'03 & 14.8 & 35.3 & 24 & 15.2 & 32.6 & 23 \\
\hline Dec - Jan’04 & 11.8 & 35.3 & 22 & 12.8 & 31.9 & 22 \\
\hline Jan - Feb'04 & 16.8 & 36.6 & 22 & 16.7 & 33.4 & 23 \\
\hline Feb - Mar'04 & 11.4 & 38.3 & 24 & 14.3 & 36.1 & 24 \\
\hline Mar - Apr'04 & 19.8 & 40.1 & 25 & 20.2 & 36.9 & 26 \\
\hline
\end{tabular}

Table II. Deposition rate of SO2 and chloride during the annual period of test

Tabla II. Velocidad de deposición de SO2 y cloruros durante el período anual del ensayo

\begin{tabular}{|c|c|c|c|c|c|}
\hline \multirow{2}{*}{ Month } & \multirow{2}{*}{ Exposure period } & \multicolumn{2}{|c|}{$\mathrm{SO}_{2}\left(\mathrm{mg} / \mathrm{m}^{2}\right.$. day $)$} & \multicolumn{2}{|c|}{$\mathrm{Cl}^{-}\left(\mathrm{mg} / \mathrm{m}^{2}\right.$. day $)$} \\
\hline & & Indoor & Outdoor & Indoor & Outdoor \\
\hline 1 & Apr-May '03 & $10.75\left(P_{1}\right)(I V)$ & - & $7.87\left(S_{1}\right)$ & - \\
\hline 2 & May-Jun ‘03 & $10.84\left(P_{1}\right)($ IV $)$ & - & $10.02\left(S_{1}\right)$ & - \\
\hline 3 & Jun-Jul ’03 & $11.60\left(P_{1}\right)($ IV $)$ & - & $13.42\left(S_{1}\right)$ & - \\
\hline 4 & Jul-Aug '03 & $10.93\left(P_{1}\right)(I V)$ & - & $4.23\left(\mathrm{~S}_{1}\right)$ & - \\
\hline 5 & Aug-Sep '03 & $16.76\left(P_{1}\right)(I V)$ & - & $9.60\left(S_{1}\right)$ & - \\
\hline 6 & Sep-Oct '03 & $6.34\left(P_{0}\right)(I I I)$ & - & $9.96\left(S_{1}\right)$ & - \\
\hline 7 & Oct-Nov '03 & $4.60\left(P_{0}\right)(I I)$ & $6.54\left(P_{0}\right)$ & $4.86\left(S_{1}\right)$ & $17.10\left(S_{1}\right)$ \\
\hline 8 & Nov-Dec '03 & $2.85\left(P_{0}\right)(I I)$ & $5.09\left(P_{0}\right)$ & $11.80\left(S_{1}\right)$ & $17.14\left(S_{1}\right)$ \\
\hline 9 & Dec-Jan '04 & $2.74\left(\mathrm{P}_{0}\right)(\mathrm{II})$ & $3.72\left(P_{0}\right)$ & $15.05\left(S_{1}\right)$ & $21.72\left(S_{1}\right)$ \\
\hline 10 & Jan-Feb ‘04 & $0.58\left(P_{0}\right)(I)$ & $1.57\left(\mathrm{P}_{0}\right)$ & $19.32\left(S_{1}\right)$ & $24.93\left(S_{1}\right)$ \\
\hline 11 & Feb-Mar `04 & $0.69\left(P_{0}\right)(I)$ & $1.69\left(P_{0}\right)$ & $13.32\left(S_{1}\right)$ & $34.87\left(\mathrm{~S}_{1}\right)$ \\
\hline 12 & Mar-Apr '04 & $1.83\left(\mathrm{P}_{0}\right)(\mathrm{II})$ & $3.32\left(P_{0}\right)$ & $30.17\left(S_{1}\right)$ & $36.26\left(S_{1}\right)$ \\
\hline
\end{tabular}

Note: $10 \mathrm{mg} / \mathrm{m}^{2}$.day is ? $12 \mathrm{~g} / \mathrm{m}^{3}$. In parenthesis are given the pollution categories for sulfur compounds, based on sulfur dioxide levels $(\mathrm{P})$ and pollution category based on airborne salinity contamination (S), according to ISO 9223:92 for outdoor (exterior) atmospheres and their significance for standard metals [23]. The lowest categories $P_{0}$ and $S_{1}$ are considered to be the background concentration and insignificant from the point of view of corrosive attack. In the second parenthesis is the level for $\mathrm{SO}_{2}$ gaseous pollutant for the indoor (cabinet) environment, according to [22].

door) are equal ( $\mathrm{S}_{1}$ and $\left.\mathrm{P}_{0}\right)$, according to ISO $9223^{[23]}$. However, from indoor corrosion point of view ${ }^{[22]}$, the level of $\mathrm{SO}_{2}$ pollutant is reaching very high levels, changing with seasons significantly from the highest level IV (during the period April -August) to the lowest one (level I) during the dry season (January March). This fact reveals that the indoor metal corrosion should be well accelerated.

\subsection{Determination of corrosion attacks}

In the end of each exposure period (1, 3, 6, 9 and $12 \mathrm{~m}$ ), samples of each metal where withdrawn. For evaluation of the corrosion effect on the metals, mass increase (MI) and mass loss (ML) measurements were performed. Both methods have a precision of about $\pm 10 \mathrm{mg} / \mathrm{m}^{2}$ with the method described $\mathrm{in}^{[22]}$. For mass 
Table III. Annual corrosion rate measurements by mass loss $\left(r_{\text {corr }}\right)$ determination and mass increase $\left(r_{\text {mi }}\right)$ of specimens exposed to indoor tropical urban-marine environment (Gulf of Mexico)

Tabla III. Velocidad anual de corrosión basada en la determinación de pérdida de masa $\left(r_{\text {corr }}\right)$ e incremento de masa $\left(r_{\text {mi }}\right)$ de muestras expuestas en "indoor" clima tropical húmedo urbano-marino (Golfo de México)

\begin{tabular}{ccccc}
\hline & \multicolumn{2}{c}{ Annual corrosion rate of mass increase } & \multicolumn{2}{c}{ Annual corrosion rate of mass loss } \\
\hline Metal & $\mathbf{r}_{\mathbf{m i}}\left(\mathbf{g} / \mathbf{m}^{2} . \mathbf{a}\right)$ & Corrosivity category & $\mathbf{r}_{\text {corr }}\left(\mathbf{g} / \mathbf{m}^{2} . \mathbf{a}\right)$ & Corrosivity category \\
\hline $\mathrm{Sn}$ & 3.23 & - & 5.43 & - \\
$\mathrm{Ni}$ & 1.88 & - & 0.89 & - \\
$\mathrm{Fe}$ & 58.01 & $\mathrm{IC} 5$ & 94.66 & IC 5 \\
& & & $(\approx 12 \mu \mathrm{m} / \mathrm{a})$ & $(\mathrm{C} 5 ;>\mathrm{C} 5)$ \\
\hline
\end{tabular}

Note: According to [22] IC5 represents "very high indoor corrosivity" of the atmosphere. In parenthesis is given the equivalent corrosivity category (C) for the outdoor (exterior) atmosphere [23], based on annual corrosion rate of standard low carbon steel samples, that have been exposed and study in this work and also in several test station located in the Caribbean area (Gulf of Mexico) [25].

increasing determination, before weighting, the exposed samples were blown by a jet stream of gas in order to remove dust and other loose particles. The final weigth of the specimens was measured using a micro-balance with an accuracy of $\pm 1 \times 10^{-7} \mathrm{~g}$. Following the mass increase determination, the metallic specimens of tin, nickel and iron were subjected to chemical pickling in specific solutions, to remove the corrosion products from the surface ${ }^{[22]}$, degreased with ethanol in a ultrasonic bath for $5 \mathrm{~min}$ and weighted using the micro-balance. All results present in this study are average of triplicate samples.

\subsection{SEM and XRD analysis}

The phase composition of the corrosion products was determined on a Siemens D5000 diffractometer with $\mathrm{CuKa}_{1}$ monochromatic radiation. Two different geometry X-ray diffraction, scanning electron microscopy and EDAX (XL ESEM Phillips) were used to analyze the phase composition of the corrosion products, their morphology and corrosion attack within the time of exposure.

\section{RESULTS AND DISCUSSION}

The detailed analysis of the indoor (cabinet) environment is described in the experimental part of this work, which permits to understand the atmospheric corrosion of the studied metals. Table III ${ }^{[25]}$ shows the average of annual corrosion rates ( $r$ ) of mass increase (MI) and mass loss (ML) for the metal samples tin, nickel and iron samples, used for a classification of corrosivity of the indoor (cabinet) and outdoor environments. As can be seen, the created indoor environment in the cabinet represents very high corrosivity: the highest category of corrosiveness -IC $5^{[22]}$. The mass loss annual rate of the tin and iron samples is higher than their mass increase rate, except for nickel samples. The experimental results show that the annual corrosion rate of nickel (Table III) based on mass loss $\left(0.89 \mathrm{~g} / \mathrm{m}^{2} . \mathrm{a}\right)$ is approximately half of the corresponding weight increase value $\left(1.88 \mathrm{~g} / \mathrm{m}^{2}\right.$.a). Probably this is due to the fact that the mass increase determination is limited by the difficulty to distinguish corrosion effects from other surface related phenomena, such as sorption or contamination (deposition of dust and other particles) ${ }^{[20]}$. The same effect and difference has been reported between both mass parameters after 8 years of exposure of nickel samples in indoor environments (inside a box ${ }^{[10]}$. It is considered that this fact could be explain by the presence of crystalline water in the corrosion products and other weight increase sources, such as particles and dirt, and also other corrosion product not detectable by XPS and $\mathrm{X}$-ray diffraction. As can be seen (Table II), during the annual of test the concentration of sulfur compounds $\left(\mathrm{SO}_{2}\right)$ in the indoor environment is changing from the highest (level IV) to the lowest one (level I), that provide different acceleration in the corrosion rate of nickel samples during the annual period of test.

\subsection{Specifics of tin (Sn) indoor corrosion}

It has been reported that tin weight increase in indoor environments (inside a box) doetin't correlate to the measured gaseous pollutants ${ }^{[10]}$. Its corrosion products consist of oxides with different stoichiometry. The only parameter that correlates with tin is the chloride concentration in precipitation on its surface. In our study was detected by XRD analysis (grazing incidence) a very low content of $\mathrm{SnCl}_{2} \cdot 2 \mathrm{H}_{2} \mathrm{O}$ since the first month of exposure of samples in the tropical ma- 


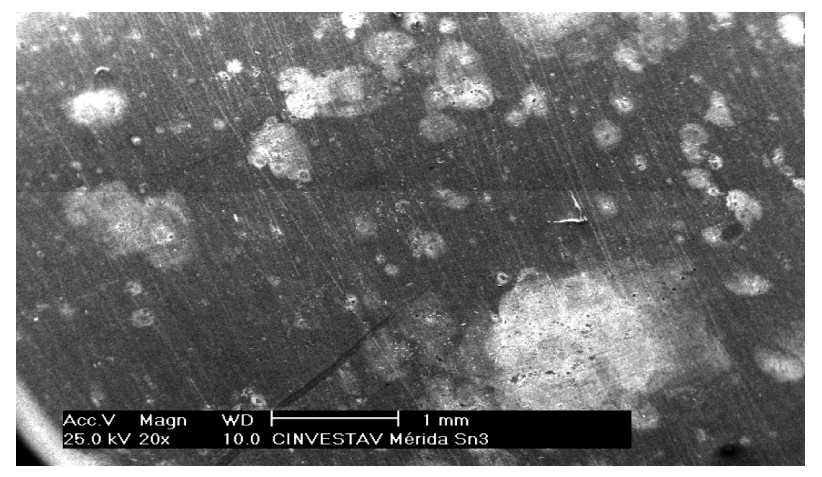

Figure 3. SEM photograph showing the localized pitting corrosion, breakdown of the tin oxide passive film in presence of $\mathrm{Cl}^{-}$ions, after $3 \mathrm{~m}$ of exposure of tin samples to urbanmarine humid tropical climate in indoor (cabinet) conditions.

Figura 3. SEM imagen mostrando la corrosión localizada por picaduras, el rompimiento de la capa de oxido de estaño en la presencia de iones de $\mathrm{Cl}$, después de $3 \mathrm{~m}$ de exposición de muestras de Tin en clima tropical húmedo urbano-marino en condiciones de "indoor" (armario).

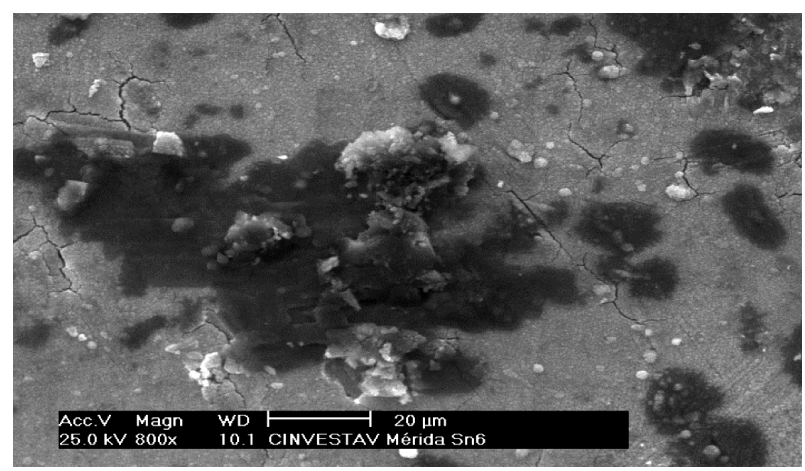

Figure 4. SEM photograph showing the appearance of black spots after $6 \mathrm{~m}$ of exposure of tin samples to urban-marine humid tropical climate in indoor (cabinet) conditions.

Figura 4. SEM imagen mostrando la aparición de puntos negros después de $6 m$ de exposición de muestras de estaño en clima tropical húmedo urbano-marino en condiciones "indoor" (armario).

rine indoor atmosphere. This fact is an indication for the $\mathrm{Cl}^{-}$ion effect on tin corrosion and the role of chloride for the breakdown of the passive tin oxide film, which promotes much localized corrosion on the tin surface (Fig. 3).

It has been reported that in polluted humid air, containing $\mathrm{SO}_{2}$, the corrosion products formed on tin are oxides $\left(\mathrm{SnO}_{2} \text { and/or } \mathrm{SnO}\right)^{[7]}$. In our study SEM/EDAX elemental analysis confirms the presence of the oxygen, as a mainly part of the tin oxide passive film, chloride and $\mathrm{Si}$, as a dust deposited on the tin surface, originated from the sand coast area. During the time of exposure were detected by SEM black spots with different sizes (Fig. 4) and using a low po-

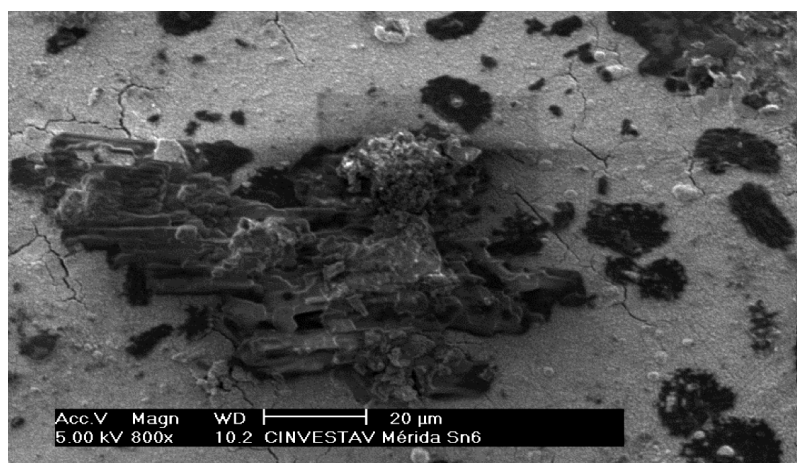

Figure 5. SEM photograph showing the morphology of typical organic material (black spots) formed after $6 \mathrm{~m}$ of exposure of tin samples to urban-marine humid tropical climate in indoor (cabinet) conditions.

Figura 5. SEM imagen mostrando la morfología típica de material orgánico (puntos negros), formados después de $6 \mathrm{~m}$ de exposición de muestras de Tin en clima tropical húmedo urbano-marino en condiciones "indoor" (armario).

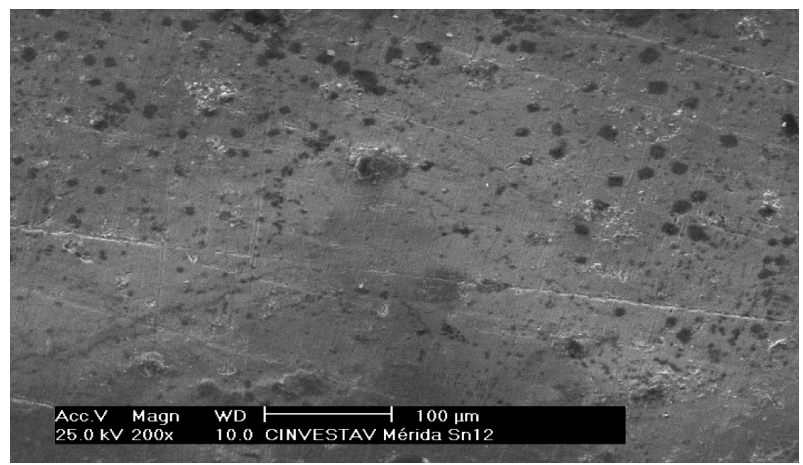

Figure 6. SEM photograph showing the extension of black spots formed after $12 \mathrm{~m}$ of exposure of tin samples to urban-marine humid tropical climate in indoor (cabinet) conditions.

Figura 6. SEM imagen mostrando la extensión de puntos negros formados en muestras de Tin despues de $12 \mathrm{~m}$ de exposición en clima tropical húmedo urbano-marino en condiciones "indoor" (armario).

wer of SEM ( $2 \mathrm{kV}$ or $5 \mathrm{kV}$ ), the black spots present a morphology of typical organic material (Fig. 5).

With the exposure time, the black pots cover more area on the tin surface (Fig. 6) and the pitting corrosion (a breakdown of the passive oxide film) follows its development: new pitting appears, extending its area with the time and going deeper into the tin surface (Fig. 7).

The mass loss and mass increase values of the tin samples are presented in Table III. It can be seen that the mass loss is higher than its corresponding values of mass increase. An analysis has been undertaken in which the extent of corrosion $\mathrm{C}$, expressed by the mass loss of the metal in indoor box, has been related to 


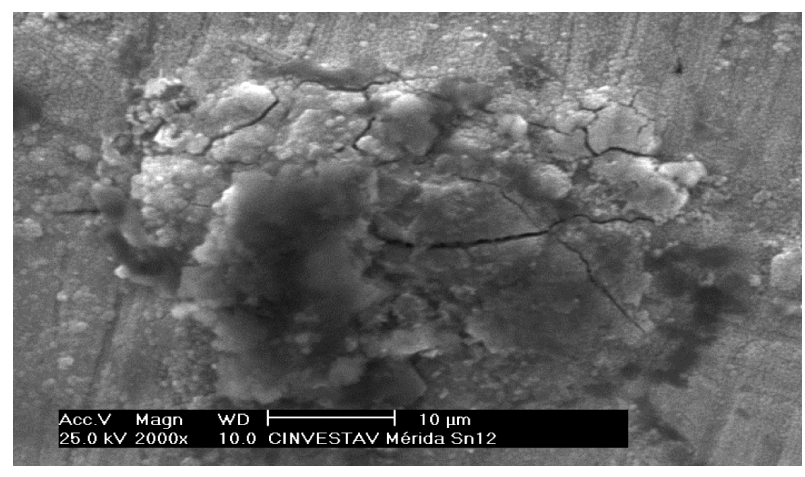

Figure 7. SEM photograph showing the pitting corrosion development on the tin surface after $12 \mathrm{~m}$ of exposure to urbanmarine humid tropical climate in indoor (cabinet) conditions.

Figura 7. SEM imagen mostrando la corrosión por picaduras desarrollada en la superficie de estaño después de $12 \mathrm{~m}$ de exposición en clima tropical húmedo urbano-marino en condiciones "indoor" (armario).

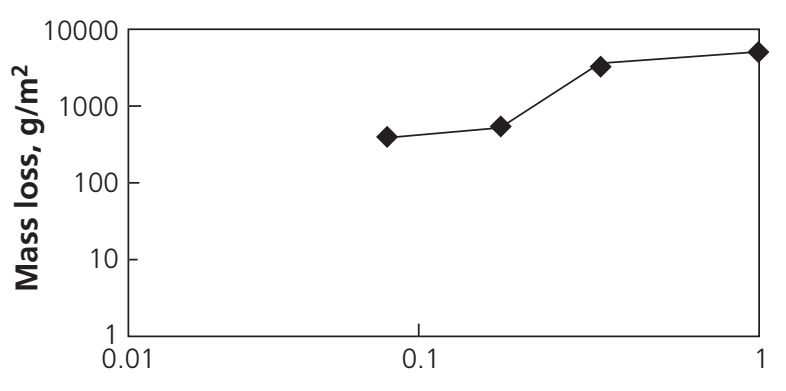

Fraction of anual TOW

Figure 8. Mass loss vs fraction of annual time of wetness (TOW), as real corrosion time, for tin samples exposed to urban-marine humid tropical climate in indoor (cabinet) conditions.

Figura 8. Pérdida de masa vs la fracción del tiempo de exposición (TOW) anual, como tiempo real de corrosión, de muestras de Tin expuestas en clima tropical húmedo urbano-marino en condiciones "indoor" (armario).

the time of wetness $t$ corresponding to each exposure period (Fig. 8). The analysis shows that the relation between $A$ and $t$ during the annual exposure can be described by the power equation $\mathrm{C}=A t^{n}$, where $A$ is the annual weight loss corresponding to annual TOW, and $n$ is the exponent giving indication of the type of kinetics. It can be seen that the fitting of the logarithmic description of corrosion rates (mass loss or mass increase per area) versus the real exposure time - TOW $(\boldsymbol{t})$ is a relatively straight line. (This line could be really straight if for the calculus of mass loss is taken only corroded (pitted) sample area and not the geometrical sample area. The SEM images presented above (Figs. 3-6) show that corrosion is not uniformly on tin). Similar equation has been reported ${ }^{[10}$ y 17$]$.

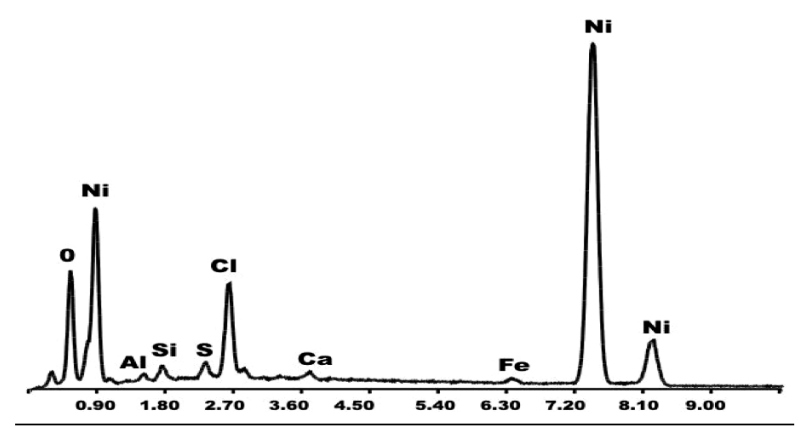

Figure 9. Elemental analysis (SEM/EDAX) of the nickel surface after $12 \mathrm{~m}$ exposure to urban-marine tropical climate in indoor (cabinet) conditions.

Figura 9. Análisis elemental (SEMIEDAX) de la superficie de níquel después de 12 m de exposición en clima tropical húmedo urbano-marino en condiciones indoor (armario).
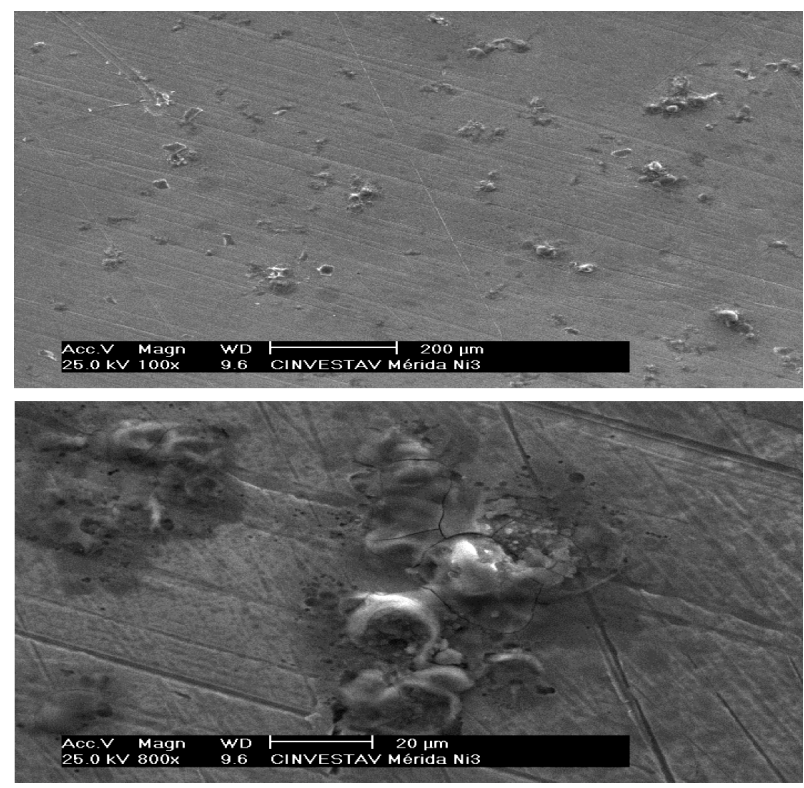

Figure 10. SEM photograph showing the localized pitting corrosion, breakdown of the $\mathrm{NiO}$ passive film in presence of $\mathrm{Cl}^{-}$ions, after $3 \mathrm{~m}$ of exposure of nickel samples to urbanmarine humid tropical climate in indoor (cabinet) conditions.

Figura 10. SEM imagen mostrando la corrosión localizada por picaduras, el rompimiento de la película pasiva de $\mathrm{NiO}$ en la presencia de iones de $\mathrm{Cl}$, después de $3 \mathrm{~m}$ de exposición de muestra de Ni en clima tropical húmedo urbano-marino en condiciones "indoor" (armario).

\subsection{Specifics of nickel (Ni) indoor corrosion}

On the nickel surface was detected by elemental analysis (SEM/EDAX) only a very thin layer of $\mathrm{NiO}$ as a corrosion product (Fig. 10) and as a principal contaminant of the marine environment - the chloride. Several other elements ( $\mathrm{Si}, \mathrm{Ca}$ ) are present on the metal surfa- 
INITIAL STAGES OF INDOOR ATMOSPHERIC CORROSION OF ELECTRONICS CONTACT METALS IN HUMID TROPICAL CLIMATE: TIN AND NICKEL ETAPAS INICIALES DE CORROSIÓN ATMOSFÉRICA INDOOR DE METALES ELECTRÓNICOS DE CONTACTO EN CLIMA TROPICAL HÚMEDO: ESTAÑO Y NÍQUEL
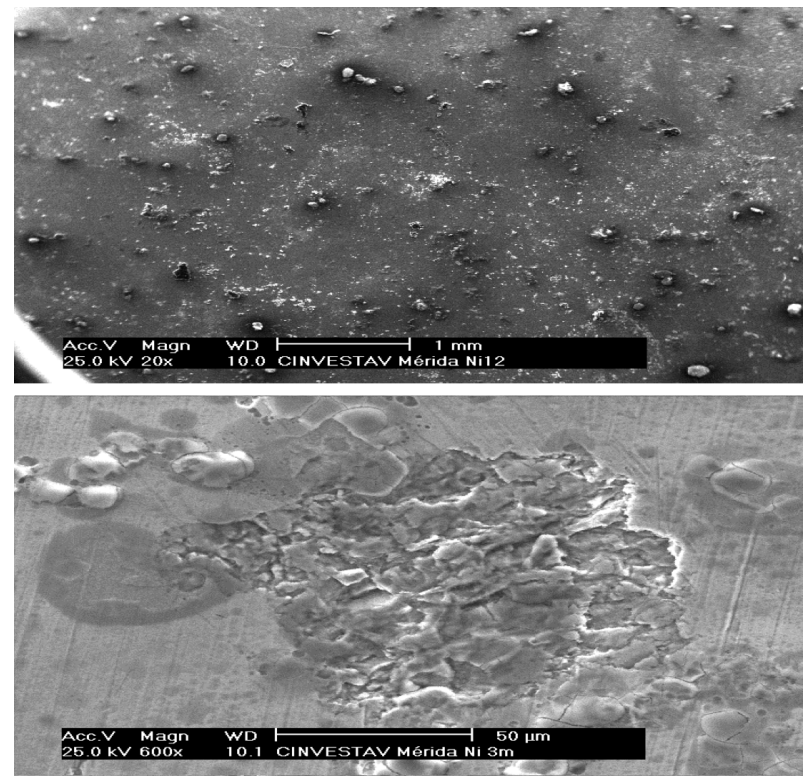

Figure 11. SEM photograph showing the localized pitting corrosion, breakdown of the $\mathrm{NiO}$ passive film in presence of $\mathrm{Cl}^{-}$ions, after $12 \mathrm{~m}$ of exposure of nickel samples to urbanmarine humid tropical climate in indoor (cabinet) conditions.

Figura 11. SEM imagen mostrando la corrosión localizada por picaduras, el rompimiento de la película pasiva de $\mathrm{NiO}$ en la presencia de iones de Cl, después de $12 \mathrm{~m}$ de exposición de muestra de Ni en clima tropical húmedo urbano-marino en condiciones indoor (armario).

ce, as a dust, originated from the sand coast area. The peak of $\mathrm{S}$ is also detected by SEM/EDAX, however another corrosion product was not detected by X-ray diffraction (grazing incidence), even after one year exposure of nickel samples in indoor marine environment.

It has been reported that the initial corrosion behavior of nickel exposed under sheltered conditions in a rural atmosphere, investigated for short-term period (from 1 day to $4 \mathrm{~m}$ and up to 1.5 years) and follows several steps ${ }^{[26]}$. Within hours of exposure, a thin layer of $\mathrm{NiO} / \mathrm{Ni}(\mathrm{OH})_{2}$ could be detected by XPS. Nickel sulfate is observed within days of exposure, by repeated dry/wet evaporation cycles and by increased levels of sulfate-containing atmospheric constituents. After 1 year of exposure, $\mathrm{NiSO}_{4} \cdot 6 \mathrm{H}_{2} \mathrm{O}$ could be detected by Xray diffraction with grazing incidence. SEM/EDAX revel evidence that this corrosion product forms dendritic structure, which grows laterally on top on $\mathrm{NiO} / \mathrm{Ni}(\mathrm{OH})_{2}$ covered surface.

In our study the SEM images reveal that there is a localized corrosion (pitting formation) due to the presence of $\mathrm{Cl}^{-}$ions, which promote a breakdown of the nickel oxide passive film (Fig. 10). The pitting corrosion starts since the first month of exposure and it is extending with the time. The extended pitting corrosion attack on the nickel surface after 12 month of exposure in indoor marine environment is shown in Fig. 11.

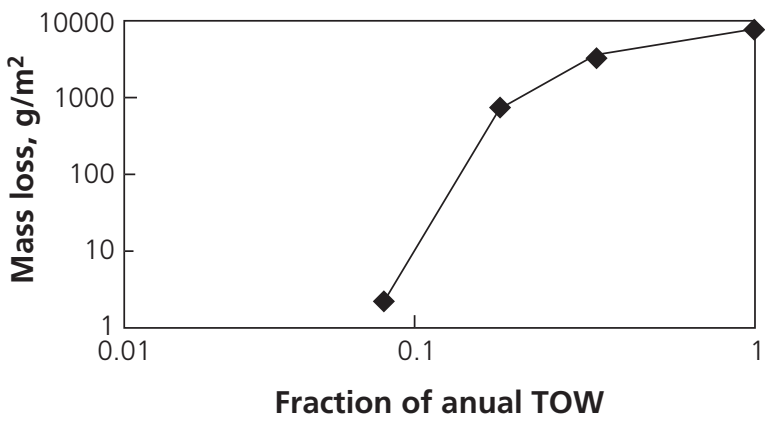

Figure 12. Mass loss vs fraction of annual time of wetness (TOW), as real corrosion time for nickel samples, exposed to urban-marine humid tropical climate in indoor (cabinet) conditions for different periods (1, 3, 6 and $12 \mathrm{~m}$ ).

Figura 12. Pérdida de masa vs la fracción del tiempo de exposición (TOW) anual, como tiempo real de corrosión, de muestras de Ni expuestas en clima tropical húmedo urbano-marino en condiciones indoor (armario).

The weight loss and mass increase values of the nickel samples are presented in Table III. It can be seen that the mass loss values of the nickel samples are twice lower than corresponding mass increase ones. The kinetics of nickel mass loss has been related to the time of wetness $t$ corresponding to each exposure period to urban-marine humid tropical climate in indoor (cabinet) atmosphere (Fig. 12).

As can be seen, the logarithmic description of the corrosion rates (mass loss or mass increase) to the real exposure time (TOW) (t) is not a straight line, as this was observed for the tin samples (Fig. 8). This fact indicates that for tin and nickel samples in indoor conditions, the relation between mass loss (C) and $\boldsymbol{t}$ (TOW) during the annual exposure period can not be described by the same power equation $C=A t^{n}$. It has been reported that the corrosion kinetics of nickel in indoor conditions is linear or exponentially dependent on relative humidity values ${ }^{[10}$ y 15] . The partial pressure of $\mathrm{SO}_{2}$ significantly influences nickel corrosion, while $\mathrm{H}_{2} \mathrm{~S}$ and $\mathrm{O}_{3}$ have little influence. Nickel corrodes in indoor environments at rates significantly less than those outdoors, and follows logarithmic normal statistics. However, should be stressed, that the not-uniform corrosion attack (Figs. 10-11) does not permit to determine the real corroded area that can be used for calculation of the weight loss values per area $\left(\mathrm{mg} / \mathrm{m}^{2}\right)$. This fact can probably change the nickel kinetic tendency from lineal to its exponential form.

\section{CONCLUSIONS}

Samples of electrolytic tin and nickel have been exposed during one year in a very high corrosive (CI5) indoor (in rain sheltered cabinet) environment, due to 
the specifics of the urban-marine humid tropical climate (Gulf of Mexico): high annual values of TOW (5620 $\mathrm{h})$, which time is distributed in high temperature ranges $\left(90 \%\right.$ of TOW in $20^{\circ}-25^{\circ} \mathrm{C}$ ). The initial stages ( 1 to $12 \mathrm{~m}$ ) of atmospheric corrosion of both metals reveal that the mass loss of tin samples is higher than its corresponding values of mass increase. However, Nickel samples mass loss values are twice lower than corresponding ones to its mass increase. The relation between mass loss or mass increase (C) and time of wetness $\boldsymbol{t}$ (as real corrosion time) during the annual exposure period can be described by the exponential law: $C=A t^{n}$ for tin samples. Due to the presence of chloride contamination SEM images reveal a breakdown of the passive oxide layers formed on tin and nickel surfaces and the development of pitting corrosion during the first month of exposure. Within the annual period, the pitting corrosion is extending on the nickel surface, promoting more significant corrosion attack. XRD analysis detects $\mathrm{SnCl}_{2} \cdot 2 \mathrm{H}_{2} \mathrm{O}$ as a corrosion product on the tin surface. The nickel surface is covered by oxide passive layer and several elements (Ca, Si, Cl) deposited on it, as a part of the sand and sea dust in the marine area. The SEM images show the appearance of black spots on the tin surface, which morphology corresponds to an organic material.

\section{Acknowledgments}

The authors would like to thank the Spanish agency CYTED for financial support of Iberoamerican project TROPICORR. This exposure program of metals is also result of the co-operation between CINVESTAV- Merida (Applied Physics Department), Mexico and Universidad Autonoma de Campeche (UAC), Programa de Corrosion de Golfo de Mexico. The authors are grateful to M. Sci. Daniel Aguilar and Ing. William Cauich, from CINVESTAV Mérida, for their assistance in X-ray and SEM data registration and also to W. Denegri from UAC.

\section{REFERENCES}

[1] E. White, G. Slenski And B. DobBs, Corrosion, Vol. 13, ASM Handbook, J. R. Davis (Ed.), ASM International, USA, 1987, pp. 1113-1126.

[2] R. BABOIAN, Corrosion Tests and Standards, Application and Interpretation, $2^{\text {nd }}$ ed., R. Baboian (Ed.), ASTM International, West Conshohocken, PA, USA, 2005, pp. 754-761.

[3] R. P. FrANKENTHAL, Uhlig's Corrosion Handbook, $2^{\text {nd }}$ ed., R. Winston (Ed.), John Wiley \& Sons, Inc., N.Y., USA, 2002, pp. 941- 947.
[4] C. Leygraf, Corrosion Mechanism in Theory and Practice, P. Marcus and J. Oudar (Eds.), Marcel Dekker, Inc, N. Y., USA, 1995, pp. 447-455.

[5] R. Schubert, A. Veca And E. Fischer, Corrosion of Electronic and Magnetic Materials, Ph. J. Peterson (Ed.), ASTM STP 1148, ASTM International, West Conshohocken, PA, USA, 1992, pp.1-10.

[6] D. W. Rice, R. J. Cappell, W. Kinsolving and J. J. LASKOWSKI, J. Electrochem. Soc. 127 (1980) 891901.

[7] T. Sasaki, T. Kanagawa, T. Ohtsuka and K. MiuRA, Corr. Sci. 45 (2003) 847-854.

[8] M. Pourbaix, Atlas of Electrochemical Equilibria in Aqueous Solutions, NACE International, Houston, TX, USA, 1974, p.477.

[9] S. ZAKIPOUR AND C. LEYGRAF, J. Electrochem. Soc. 133 (1986) 21-30.

[10] J. Tidblad and V. Kucera, Report 26, Swedish Corrosion Institute, Stockholm, Sweden, 1998.

[11] E. SikORA AND D. D. MACDONALD, Electrochem. Acta 48 (2002) 69-77.

[12] D. W. Rice, P. B. Phipps and R. Tremoureux, J. Electrochem. Soc. 127 (1980) 563-568.

[13] D. Persson and C. Leygraf, J. Electrochem. Soc. 139 (1992) 2243-2249.

[14] D. Persson And C. Leygraf, J. Electrochem. Soc. 142 (1995) 1468-1477.

[15] T. E. GRAedel AND C. LEygraf, J. Electrochem. Soc. 147 (2000) 1010-1014.

[16] E. Johansson, C. Leygraf and B. Rendahl, $B r$. Corr. J. 33 (1998) 59-66.

[17] J. Tidblad, V. KuCERA AND A. MikHailov, UN/ECE Report 30, Swedish Corrosion Institute, Stockholm, Sweden, 1998.

[18] ANSI/ISA-SP71, Airborne Contaminants Instrument Society of America, Research Triangle Park, NC, USA, 1997.

[19] M. Forslund, J. Majoros, C. Leygraf, J. Electrochem. Soc. 144 (1997) 2637-2642.

[20] E. Johansson, C. Leygraf, Br. Corros. J. 34 (1999) 27-33.

[21] L. Veleva L., G. Pérez G., M. Acosta, Atmos. Environ. 31 (1997) 773-776.

[22] ISO Standard 1844-04, ISO, Geneve, Switzerland, 2004.

[23] ISO Standard 9223-92, ISO, Geneve, Switzerland, 1992.

[24] ISO Standard 9225-92, ISO, Geneve, Switzerland, 1992.

[25] L. Veleva, L. Maldonado, Br. Corros. J. 33 (1998) 53-57.

[26] I. OdNEVAlL, C. Leygraf, J. Electrochem. Soc. 144 (1997) 3518-3525. 